\title{
PHYSICS ANALYSIS OF THE GANG PARTIAL ROD DRIVE EVENT (U)
}

\author{
by C. Boman
}

Westinghouse Savannah River Company

Savannah River Site

Aiken, South Carolina 29808

Other Authors:

R. L. Frost

(WSRC)

This paper was prepared in connection with work done under Contract No. DE-AC09-89SR18035 with the U. S. Department of Energy. By acceptance of this paper, the publisher and/or recipient acknowledges the U. S. Government's right to retain a nonexclusive, royalty-free license in and to any copyright covering this paper, along with the right to reproduce and to authorize others to reproduce all or part of the copyrighted paper. 


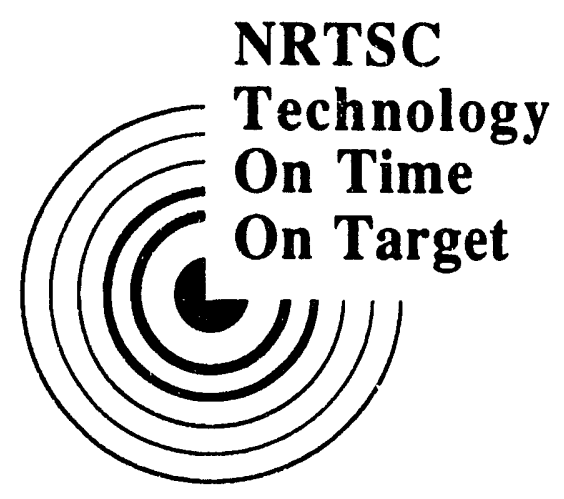

KEY WORDS:

SAFETY ANALYSIS

PARTIAL ROD

RETENTION PERIOD:

LIFETIME

\title{
PHYSICS ANALYSIS OF THE GANG PARTIAL ROD DRIVE EVENT (U)
}

\author{
B y
}

Christa Boman

Robert L. Frost

ISSUED: August 1992

SRL SAVANNAH RIVER LABORATORY, AIKEN, SC 29808 Westinghouse Savannah River Company

Prepared for the U. S. Department of Energy under Contract DE-A C 09-8\$SR 18035 
DOCUMENT: WSRC-TR-92-0401

TITLE: PHYSICS ANALYSIS OF THE GANG PARTIAL ROD DRIVE EVENT (U).

TASK: Physics Analysis to Account for APM Rod Uncertainties $\quad(92.051-1)$

APPROVALS

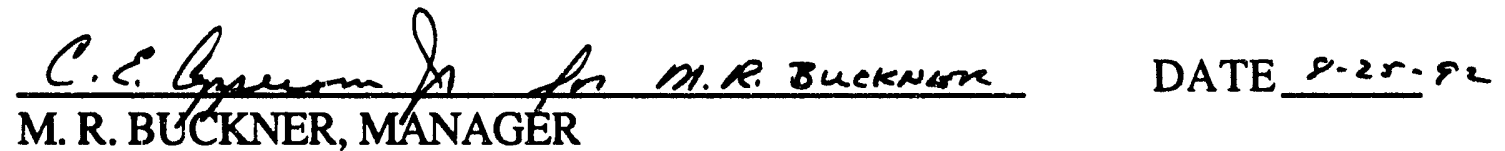
SCIENTIFIC COMPUTATIONS SECTION

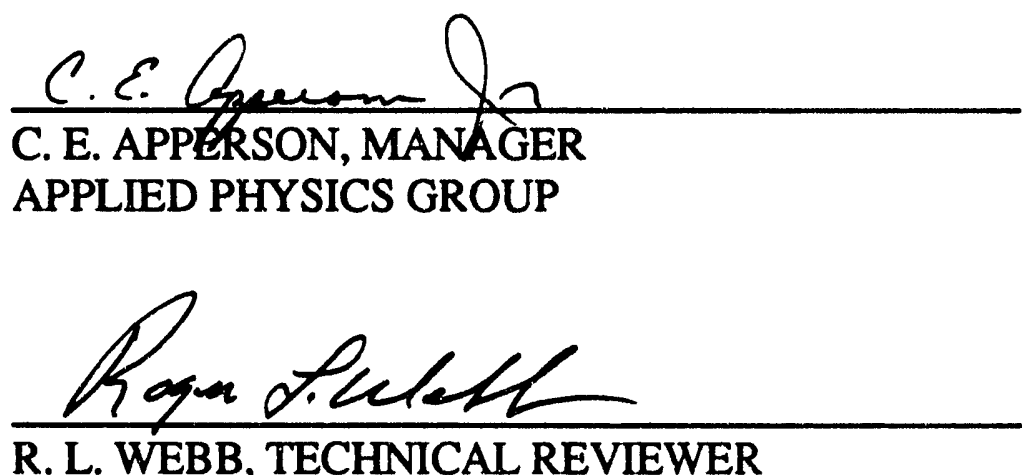

DATE $8-25=92$

C. E. APPERSON, MANAGER

R. L. WEBB, TECHNICAL REVIEWER

DATE $8 \cdot 2 \% \cdot 92$ 
August 24, 1992

\section{TEMPORARY DELEGATION OF AUTHORITY}

Delegating Manager

M. R. BUCKNER

Department

SCIENTIFIC COMPUTATIONS

Title MANAGER 3

I heroby delegate my signature authority to

C. E. Apperson

for the period from

August 24, 1992

to

August 25, 1992

for the reason of business travel.

Signed

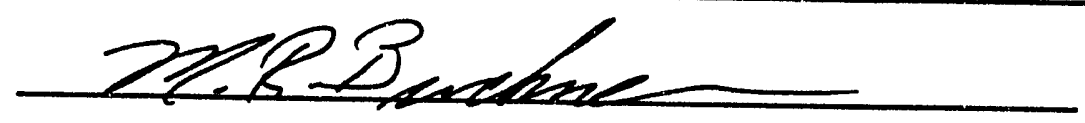

F. Beranek, 773-A

P. L. Ames, 773-59A

C. E. Apperson, 773-42A

R. R. Beckmeyer, 773-42A

E. L. Funderburk, 773-42A

J. R. Pelfrey, 773-59A

E. C. Randall, 773-22A

N. P. Baumann, 773-42A

J. P. Church, 773-42A

M. V. Gregory, 773-42A

T. G. Williamson, 773-42A

Faye Key, 773-A

Lana Widener, 773-A

Linda Griffin, 773-A

Gene Dyches, 773-A

J. O'Bryant, 742-A 


\subsection{INTRODUCTION}

During the routine positioning of partial-length control rods in Gang 3 on the afternoon of Monday, July 27, 1992, the partial-length rods continued to drive into the reactor even after the operator released the controlling toggle switch. In response to this occurrence, the Safety Analysis and Engineering Services Group (SAEG) requested that the Applied Physics Group (APG) analyze the gang partial rod drive event. Although similar accident scenarios were considered in analysis for Chapter 15 of the Safety Analysis Report (SAR), APG and SAEG conferred and agreed that this particular type of gang partial-length rod motion event was not included in the SAR.

The gang partial rod drive (GPRD) event is the uncontrolled withdrawal or insertion of the partial-length control rods in every cluster of the affected gang. It is similar to the gang rod withdrawal (GRW) accident which is the uncontrolled withdrawal of the full-length rods in every cluster of the affected gang. In both accidents, an initiating event causes an uncontrolled movement of an entire gang of control rods. A second failure then causes the rods to move at a higher speed. In the GRW, the controlling full-length control rod in each cluster of the affected gang is withdrawn from the core (insertion would result in a negative reactivity addition), while in the GPRD event, the partial-length control $\operatorname{rod}(\mathrm{s})$ in each cluster of the affected gang are either withdrawn or inserted. With partial-length control rods, a positive reactivity change can result from either insertion or withdrawal of the rods. Other differences between the GPRD and the GRW are:

(1) In the GRW event with the worst accompanying single failure, full-length control rods withdraw at $135 \mathrm{vu} / \mathrm{min}$ while partial-length control rods withdraw at $95 \mathrm{vu} / \mathrm{min}$ in the GPRD event with the worst accompanying single failure;

(2) Technical Specifications require at least a weak partiallength control rod when more than 350 vu of full-length control rod is inserted in the reactor, therefore, the controlling 


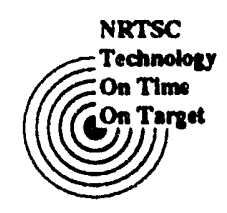

Physics Analysis of the Gang

WSR C-TR-92-0401

August, 1992

Partial Rod Drive Event

Page 2 of 14

rod being withdrawn in the GRW is shadowed. In the GPRD event, the affected partial-length rods do not have to be shadowed; and

(3) In the GPRD event, strong and weak partial-length control rods can withdraw or insert together. In the GRW, only the controlling rod, which in the limiting case is a weak full-length rod, can withdraw.

Under certain conditions, the gang rod withdrawal accident bounds (produces a higher reactivity addition rate) the gang partial rod drive event. Because there was interest in determining under what conditions the GRW event bounded the GPRD event, the gang partial rod drive accident was not analyzed just for the maximum reactivity addition rate, but it was also analyzed for conditions which were bounded by the GRW. Specifically, the gang partial rod drive event was analyzed under the following conditions:

(1) Unshadowed* double partial-length rods in the affected gang;

(2) Shadowed* double partial-length rods in the affected gang; and

(3) Unshadowed weak partial-length rods in the affected gang.

The assumptions chosen, the calculational methods used, and the results generated for the partial rod drive event are the subject of this report. This work has been performed under QA task plan number 92-051-1.

\subsection{SUMMARY}

The Gang 3 partial rod drive event that occurred on July 27, 1992 during operation of the K-14 Mark 22 charge resulted in core reactivity effects that were at all times within the allowed values for safe reactor operation

\footnotetext{
* Clusters with unshadowed partial-length control rods have greater than 100 and less than $1000 \mathrm{vu}$ of full-length control rod, and clusters with shadowed partiallength rods have at least 1000 of full-length rod.
} 
previously determined by the analysis of the gang rod withdrawal accident described and documented in Chapter 15 of the Safety Analysis Report. Although analysis of the gang partial rod drive event indicates that there are certain reactor operating conditions under which the gang rod withdrawal accident does not bound the generic GPRD event (see Section 3.0 ), the reasons listed below explain why the specific event that occurred during K-14 operation (described above) was bounded by the GRW analysis:

(1) The partial-length control rod drive speed for the actual event was only $22.5 \mathrm{vu} / \mathrm{min}$, which is much less than the 95 $\mathrm{vu} / \mathrm{min}$ assumed for the generic analysis;

(2) There were only weak partial-length control rods in every cluster of all three gangs. As seen in Table 1, a GPRD event with only weak partial-length rods in every cluster of the affected gang is bounded by GRW;

(3) Full-length control rods were inserted in Gangs 1, 2, and 3 at $2555 \mathrm{vu}$, so the GPRD event was shadowed by two full-length control rods. Again, as seen in Table 1, a GPRD event shadowed by at least one full-length rod is bounded by GRW; and

(4) The event occurred in Gang 3 which is not the limiting gang.

Moreover, under any of the reactor conditions present during the operation of the K-14 Mark 22 charge, the GPRD event was always bounded by the GRW accident, even at the higher rod drive speed.

\subsection{RESULTS}

The results of the generic gang partial rod drive analysis are summarized in Table 1. The bounding reactivity addition rate for the GPRD event is $22.84 \mathrm{pcm} / \mathrm{sec}$. This value includes uncertainties and is based upon a maximum partial-length control rod drive speed of $95 \mathrm{vu} / \mathrm{min}$. The 
transient multiplier on peaking for this case is 2.03. This maximum reactivity addition rate occurs with a Gang 1, double partial event with the Gang 1 full-length control rods at 500 vu (condition (1) above). If the double partial-length control rods are shadowed by at least one fully inserted full-length control rod, the maximum reactivity addition rate is $12.86 \mathrm{pcm} / \mathrm{sec}$ (condition (2) above). Finally, for an unshadowed, weak only partial-length rod configuration (condition (3) above), the maximum reactivity addition rate is $12.75 \mathrm{pcm} / \mathrm{sec}$.

All results reported in Table $\mathbf{i}$ assumed a maximum partial-length control rod drive speed of $95 \mathrm{vu} / \mathrm{min}$. In addition, these bounding values were generated at a reactor power greater than the Instrument Shape Applicability Limit (ISAL) which limits the radial shape factor (RSF) to $0.72<R S F<0.95$, and the roof top ratio (RTR) to $0.62<R T R<1.44$ with uncertainties in measured axial and radial power shapes considered.

The maximum reactivity addition rate for the GRW event is $15.0 \mathrm{pcm} / \mathrm{sec}$ (Reference 1). This value also includes uncertainties and is based upon a maximum full-length control rod drive speed of $135 \mathrm{vu} / \mathrm{min}$. Therefore, the GPRD event is bounded by the GRW accident for conditions (2) and (3) of Section 1.0 .

\subsection{DISCUSSION}

\subsection{Gang Partial-Length Control Rod Drive Event Description}

The gang partial rod drive event is the uncontrolled withdrawal or insertion of the partial-length rods in every cluster of the affected gang. Positive reactivity addition rates can occur when the partial rods are being moved (either withdrawn or inserted) from a region of high worth to a region of low worth. It is similar to the gang rod withdrawal (GRW) accident, which is the uncontrolled withdrawal of the full-length rods in every cluster of the affected gang. However, no positive reactivity addition rates occur for the GRW accident when the full-length rods are inserted into the reactor. The reactivity addition of both accidents is reduced if control rod shadowing is present. Because of these shadowing 
WSR C - TR-92-0401

August, 1992

Physics Analysis of the Gang

Partial Rod Drive Event

Page 5 of 14

considerations, the gang partial rod drive event can potentially have a higher reactivity addition rate than the gang rod withdrawal event. Considering the GRW for the conditions which give rise to the maximum reactivity addition rate, shadowing of the full-length control rods by at least a weak partial-length rod is guaranteed by Technical Specifications (Table 3.2.1-1 of Reference 7). There is no similar requirement that would impact the GPRD event, which can occur unshadowed (except for $100 \mathrm{vu}$ of full-length trim) by full-length rods.

The GPRD accident is analyzed in a manner similar to the gang rod withdrawal (Reference 1) and single rod withdrawal (Reference 2) accidents. Starting from some base case, all the partial-length control rods in the affected gang are withdrawn or inserted in small increments (25 vu increments were used in this work). The reactivity addition rate is defined as the reactivity change (in $\mathrm{pcm}$ ) per vu. Multiplying by the rod drive speed gives reactivity addition rate in $\mathrm{pcm} / \mathrm{sec}$. The quantity of interest is the maximum reactivity addition rate. Figure 1 shows the maximum reactivity addition rate for a Gang 1, unshadowed double partial-length rod withdrawal from 775 to 500 veeder units. In this case, the maximum occurs as the partial-length control rods are withdrawn from $700 \mathrm{vu}$ to 675 vu. Figure 1 also shows the maximum for a Gang 1 double partiallength rod insertion from 775 to 1000 veeder units for the same initial conditions. Here the maximum occurs as the partial-length control rods are inserted from 875 vu to $900 \mathrm{vu}$.

\subsection{Calculational Methods}

For each of the selected conditions (unshadowed double partial rods, shadowed double partial rods, and unshadowed weak partial rods), acceptable base cases, with control rod complements, radial shape factors (RSF) and roof top ratios (RTR) within the analysis bands defined in Reference 1, were found by a trial and error approach. GRISET (Reference 3) was run to find the flux, eigenvalue, radial shape factor, roof top ratios, and peaking factors. The gang partial rods were then withdrawn or inserted in 25 veeder unit increments, and the eigenvalues and peaking factors were recorded at each step. 


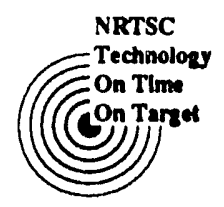

Physics Analysis of the Gang

For each condition, many different base cases were examined. The effect on the maximum reactivity addition rate of driving partial-length control rods in either Gang 1,2, or 3 was analyzed, and the effect of varying the radial shape factors and roof top ratios on the results was also analyzed.

\subsection{Parameters Affecting the Reactivity Addition Rate}

The maximum reactivity addition rate was sensitive to the flux shapes, shadowing, burnup, and gang being analyzed. The effect of each is described here.

\subsubsection{Radial Flux Shapes}

The radial flux shape has a very pronounced effect on the maximum reactivity addition rate. A radial flux peaked in the gang being analyzed produced the largest addition rates. The radial flux shape affected the addition rate more than any other factor. Specifically, the GPRD event was maximized in Gang 1 when the radial shape factor was low, in Gang 3 when the RSF was high, and in Gang 2 when the RSF was low or high (but not in the middle of the RSF range).

\subsubsection{Axial Flux Shapes}

In contrast to the pronounced effect of the radial flux shape, the preincident axial flux shape had very little effect either on the maximum reactivity addition rate or the location of the maximum. Table 2 shows the effect of the roof top ratio on the reactivity addition rates for shadowed double partial-length control rods inserted or withdrawn from Gang 3. The radial shape factor was kept constant at approximately 1.0, while the roof top ratio was adjusted for a series of cases. Various combinations of roof top ratios in the different gangs were investigated. For example, when analyzing the Gang 2 partiallength rod drive, the pre-incident roof top ratio in all gangs was increased to its upper limit, decreased to its lower limit, increased in Gangs 1 and 3 and decreased in Gang 2, and decreased in Gangs 1 and 3 
WSR C-TR-92-0401

August, 1992

Physics Analysis of the Gang

Partial Rod Drive Event

Page 7 of 14

and increased in Gang 2. These perturbations had relatively little effect on the reactivity addition rates. Similar analyses were performed for partial-length rod drives in the other two gangs.

\subsubsection{Shadowing}

The presence of full-length control rods, which shadow the partiallength control rods, reduced the reactivity addition rate. In fact, shadowing reduced the addition rate by approximately $40 \%$ as seen in Table 1. The presence of other control rods decreases the worth of the rods being withdrawn or inserted, and decreases the reactivity addition rate.

\subsubsection{Burnup Effects}

Nuclear cross section data representaive of different reactor conditions were investigated to determine which provided the most conservative analysis for the GPRD event. The maximum reactivity addition rate occurred when cold-clean end-of-cycle cross sections were used in the analysis. The fuel was depleted (end-of-cycle), but the control rods were not in order to maximize their worth. To add additional conservatism, Xe and Sm were removed (cold-clean) from the depleted fuel contents.

\subsubsection{Gang Analyzed}

Under all conditions, the maximum addition rate occurred when the partial-length rods were withdrawn or inserted in Gang 1 . Table 3 shows this with an example of one condition which was analyzed in all three gangs.

\subsection{Peaking Factors}

GRISET was used to calculate the transient multiplier on peaking (TMP), the pre-transient peaking and the post-transient peaking associated with 
the limiting case. The peaking factors were calculated with the following equations (Reference 4):

$$
\begin{gathered}
\text { TMP }=\max \left\{\frac{p_{i}(t)}{p_{i}(0)}\right\} \\
p_{i}(0)=\text { Pre }- \text { transient peaking }=\frac{p_{\max }(0)}{p_{\text {ave }}} \\
p_{i}(t)=\text { Post }- \text { transient peaking }=\frac{p_{\text {max }}(t)}{p_{\text {ave }}}
\end{gathered}
$$

$p_{i}(t)$ is the power in assembly position $i$ at 0 vu for a partial-length rod withdrawal or at $1000 \mathrm{vu}$ for an partial-length rod insertion. Note that the TMP reported is the maximum observed for the limiting case found by maximizing the reactivity addition, and it is not the largest TMP possible for the accident. No attempt was made to maximize the TMP or the pre- or post- transient peakings.

The peakings for the conditions analyzed are shown in Table 1 . The peakings in the GPRD event are larger for gang partial-length control rod withdrawal accidents than insertion accidents because the partial-length rods are worth less at $0 \mathrm{vu}$ (fully withdrawn) than $1000 \mathrm{vu}$ (fully inserted).

\subsection{Uncertainties}

Two sources of uncertainties were considered in the calculation of the maximum reactivity addition rate. The first corresponds to uncertainties in the ${ }^{6} \mathrm{Li}$ content of the control rods, while the second corresponds to the uncertainty in GLASS predictions of control rod worth. The latter will be discussed first. In Ref. 5, GLASS simulations of experimental conditions resulted in a worth of $784 \mu \mathrm{B}$ for a full septifoil ( 7 rods), compared to the $744 \mu \mathrm{B}$ experimental value. An uncertainty analysis performed using this information (Ref. 6) showed that increasing the thermal capture cross 
section by $4.4 \%$ is sufficient to account for the $+2 \sigma$ limit on calculated worth of a full septifoil. Unfortunately, no data is available for worths of se ptifoils with less than 7 rods. However, it is known that control rod worth predictions are more accurate with fewer control rods inserted in the septifoil. Therefore, by increasing the thermal macroscopic capture cross section $4.4 \%$, one can conservatively account for the difference between calculated and actual control rod worth. It should be noted that it is implicitly assumed in this work that increasing the thermal capture cross section of the driving control rods increases the incremental reactivity worth and leads to a conservative calculation. Decreasing the capture cross section by using the lower $-2 \sigma$ limit would decrease incremental reactivity worth, and thus would be non-conservative.

The second source of uncertainty considered is that associated with control rod lithium content. The Nuclear Test Gauge (NTG) is generally accepted to have an uncertainty in lithium content of $\pm 10 \%$. To account for this potential source of error, the lithium concentration in the weak and strong rods was increased by $10 \%$, and the cross sections were regenerated. The thermal capture cross section was then increased by $4.4 \%$ to account for uncertainty in the worth calculation. These new cross sections were then used in the bounding GRIMHX calculations for each scenario (unshadowed weak, shadowed doubles, and unshadowed doubles). The new cross sections were only used in the gang containing the driving partial length rods. The maximum reactivity addition rates reported in this paper include the effects of these uncertainties. No other uncertainties were included. 


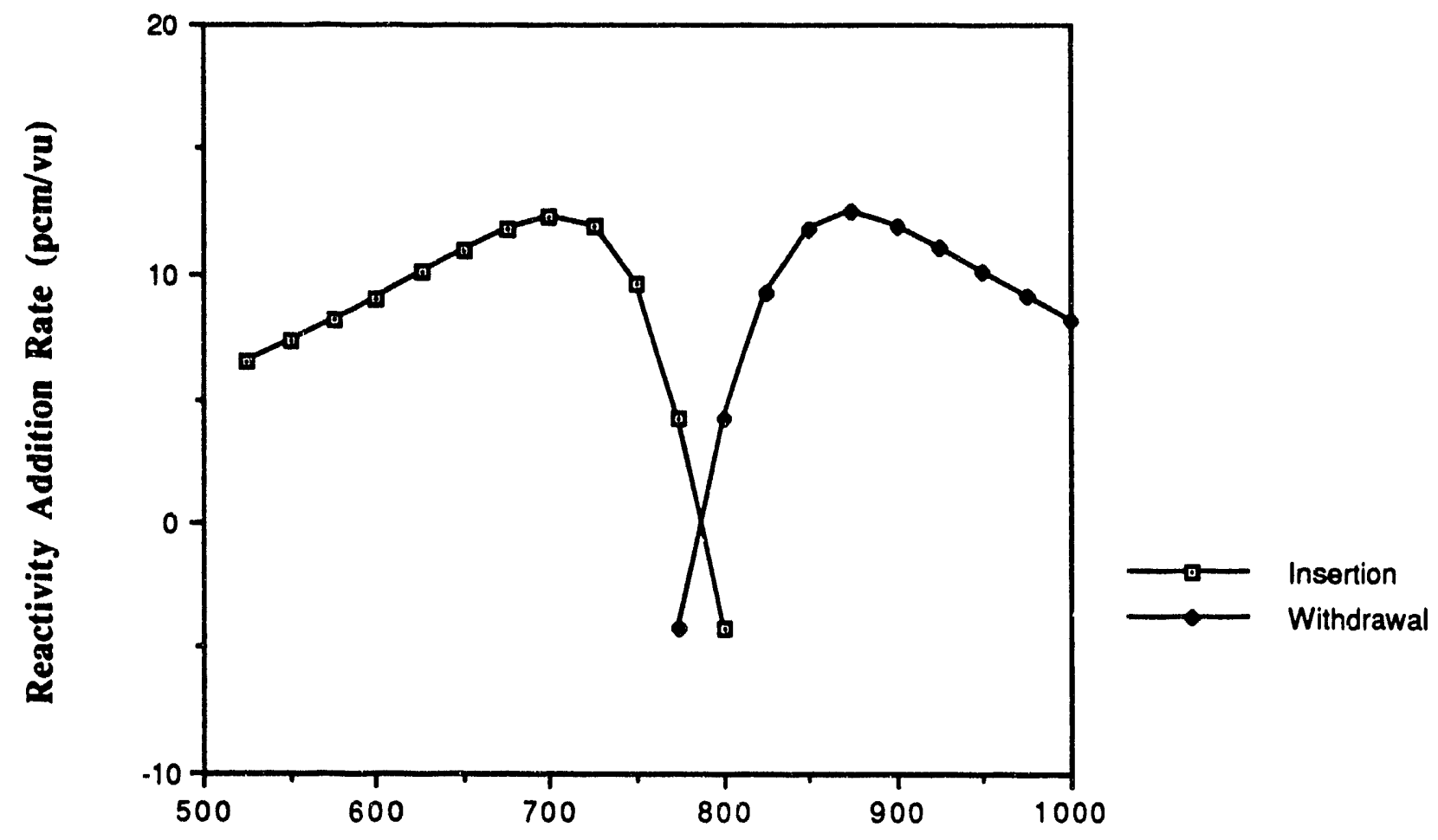

Gang 1 Partial-Length Rod Position (vu)

Figure 1 - Reactivity Addition Rate versus Gang 1 Partial-length control rod position for a gang partial rod withdrawal and insertion with associated uncertainties, and with the following initial conditions:

$$
\begin{array}{ll}
\text { Gang } 1- & 100 \text { vu full rod } \\
& 775 \text { both partials } \\
\text { Gany 2 - } & 2000 \text { vu full rod } \\
& 775 \text { both partials } \\
\text { Gang 3 - } & 700 \text { vu full rod } \\
& 835 \text { weak partials }
\end{array}
$$




\section{Table 1
Maximum Reactivity Addition Rates for the GPRD Event}

\begin{tabular}{|c|c|c|c|c|}
\hline Condition & Configuration & $\begin{array}{l}\text { Maximum } \\
\text { Reactivity } \\
\text { Addition } \\
\text { Rate* } \\
(\mathrm{pcm} / \mathrm{sec})^{* *}\end{array}$ & Location & $\begin{array}{c}\text { Transient } \\
\text { Multiplier } \\
\text { on } \\
\text { Peaking }\end{array}$ \\
\hline $\begin{array}{l}\text { (1) Unshadowed } \\
\text { double-partial } \\
\text { length control } \\
\text { rods }\end{array}$ & \begin{tabular}{|l|} 
Gang 1 \\
500 vu full-length rod \\
Double partials \\
withdrawn \\
Gang 2 \\
2000 vu full-length rod \\
775 vu double partials \\
Gang 3 \\
1500 vu full-length rod \\
825 vu weak partials \\
\end{tabular} & 22.84 & $\begin{array}{l}\text { Withdrawn from } \\
725 \text { vu to } 700 \mathrm{vu}\end{array}$ & $\begin{array}{l}2.03 \\
\text { in Cluster } 1\end{array}$ \\
\hline $\begin{array}{l}\text { (2) Shadowed } \\
\text { double partial- } \\
\text { length control } \\
\text { rods }\end{array}$ & \begin{tabular}{|l|} 
Gang 1 \\
1500 vu full-length rod \\
Double partials \\
inserted \\
Gang 2 \\
2000 vu full-length rod \\
775 vu double partials \\
Gang 3 \\
2000 vu full-length rod \\
775 vu double partials \\
\end{tabular} & 12.86 & $\begin{array}{l}\text { Withdrawn from } \\
700 \mathrm{vu} \text { to } 675 \mathrm{vu}\end{array}$ & $\begin{array}{c}1.73 \\
\text { in Cluster } 1\end{array}$ \\
\hline $\begin{array}{l}\text { (3) Unshadowed } \\
\text { weak partial - } \\
\text { length control } \\
\text { rods }\end{array}$ & \begin{tabular}{|l|} 
Gang 1 \\
100 vu full-length rod \\
Weak partials \\
withdrawn \\
Gang 2 \\
2000 vu full-length rod \\
800 vu double partials \\
Gang 3 v \\
1000 vu full-length rod \\
800 vu double partials
\end{tabular} & 12.75 & $\begin{array}{l}\text { Withdrawn from } \\
625 \mathrm{vu} \text { to } 600 \mathrm{vu}\end{array}$ & $\begin{array}{l}1.28 \\
\text { in Cluster } 1\end{array}$ \\
\hline
\end{tabular}

* With uncertainties described in Section 4.5

* at $95 \mathrm{vu} / \mathrm{min}$ 


\section{Effect of Roof Top Ratio on Reactivity Addition Rate}

\begin{tabular}{|c|c|c|c|c|c|}
\hline $\begin{array}{c}\text { Radial } \\
\text { Shape } \\
\text { Factor }\end{array}$ & $\begin{array}{c}\text { Average } \\
\text { Roof } \\
\text { Top } \\
\text { Ratio }\end{array}$ & $\begin{array}{c}\text { Maximum } \\
\text { Reactivity } \\
\text { Addition } \\
\text { Rate* for a } \\
\text { Withdrawal } \\
\text { (pcm/sec)** }\end{array}$ & $\begin{array}{c}\text { Location of } \\
\text { Maximum } \\
\text { Reactivity } \\
\text { Addition } \\
\text { Rate for a } \\
\text { Withdrawal }\end{array}$ & $\begin{array}{c}\text { Maximum } \\
\text { Reactivity } \\
\text { Addition } \\
\text { Rate* } \\
\text { Insertion } \\
\text { (pcm/sec) }\end{array}$ & $\begin{array}{c}\text { Location of } \\
\text { Maximum } \\
\text { Reactivity } \\
\text { Addition } \\
\text { Rate for an } \\
\text { Insertion }\end{array}$ \\
\hline 1.0 & 1.4 & 7.3 & $\begin{array}{c}\text { Withdrawn } \\
\text { from 675 vu to } \\
650 \mathrm{vu}\end{array}$ & 8.5 & $\begin{array}{c}\text { Inserted from } \\
875 \text { vu to } 900 \mathrm{vu}\end{array}$ \\
\hline 0.99 & 1.2 & 7.9 & $\begin{array}{c}\text { Withdrawn } \\
\text { from 650 vu to } \\
625 \mathrm{vu}\end{array}$ & 8.2 & $\begin{array}{c}\text { Inserted from } \\
875 \text { vu to } 900 \mathrm{vu}\end{array}$ \\
\hline 1.0 & 1.0 & 9.5 & $\begin{array}{c}\text { Withdrawn } \\
\text { from 700 vu to } \\
675 \mathrm{vu}\end{array}$ & 8.1 & $\begin{array}{c}\text { Inserted from } \\
900 \text { vu to } 925 \mathrm{vu}\end{array}$ \\
\hline 1.0 & 0.8 & 8.1 & $\begin{array}{c}\text { Withdrawn } \\
\text { from 675 vu to } \\
650 \mathrm{vu}\end{array}$ & 8.2 & $\begin{array}{c}\text { Inserted from } \\
950 \mathrm{vu} \text { to } 975 \mathrm{vu}\end{array}$ \\
\hline 1.0 & 0.6 & 8.4 & $\begin{array}{c}\text { Withdrawn } \\
\text { from } 700 \mathrm{vu} \text { to } \\
675 \mathrm{vu}\end{array}$ & 8.9 & $\begin{array}{c}\text { Inserted from } \\
925 \text { vu to } 950 \mathrm{vu}\end{array}$ \\
\hline
\end{tabular}

* Without uncertainties

** at $95 \mathrm{vu} / \mathrm{min}$ 
Table 3

Maximum Reactivity Addition Rates of Each Gang

\begin{tabular}{|c|l|l|l|}
\hline Condition & $\begin{array}{l}\text { Gang 1 } \\
\text { Withdrawal } \\
\text { Maximum } \\
\text { Reactivity } \\
\text { Addition Rate* } \\
\text { (pcm/sec)** }\end{array}$ & $\begin{array}{l}\text { Gang 2 } \\
\text { Withdrawal } \\
\text { Maximum } \\
\text { Reactivity } \\
\text { Addition Rate* } \\
\text { (pcm/sec) ** }\end{array}$ & $\begin{array}{l}\text { Gang 3 } \\
\text { Withdrawal } \\
\text { Maximum } \\
\text { Reactivity } \\
\text { Addition Rate* } \\
\text { (pcm/sec)** }\end{array}$ \\
\hline $\begin{array}{l}\text { (3) Shadowed } \\
\text { double partial- } \\
\text { length control rods }\end{array}$ & 12.0 & & \\
\hline
\end{tabular}

* Without uncertainties

** at $95 \mathrm{vu} / \mathrm{min}$ 


\subsection{REFERENCES}

1. R. L. Frost, S. K. Skiles, The Effect of Uncertainty in Radial Shape Factor and Tilt Ratio on the Loss of Control Rod Cooling and Gang Rod Withdrawal Accidents, Rev. 1, SRT-APG-920037, Rev. 1, August 3, 1992.

2. C. Boman, Analysis of the Single Rod Withdrawal Accident Below ISAL, SRT-APG-920058, June 19, 1992.

3. J. J. Taylor, G. R. Cefus, R. L. Webb, GRISET User's Manual, Rev, 1 (U), WSRC-TR-92-85, Rev. 1, February, 1992.

4. R. L. Frost, Definition of Peaking Factors Used by the Applied Physics Group, SRT-APG-920074, June 18, 1992.

5. W.E. Graves and R.L. Webb, GLASS Code Validation, WSRC-TR-91-002, January 1991.

6. R.L. Frost, Control and Safety Rod Worths Under Shutdown Conditions for the K-14 Mark 22 Charge, WSRC-TR-91-433, July 1991.

7. Savannah River Site Production Reactor Technical Specifications, WSRC-TS-10003. 

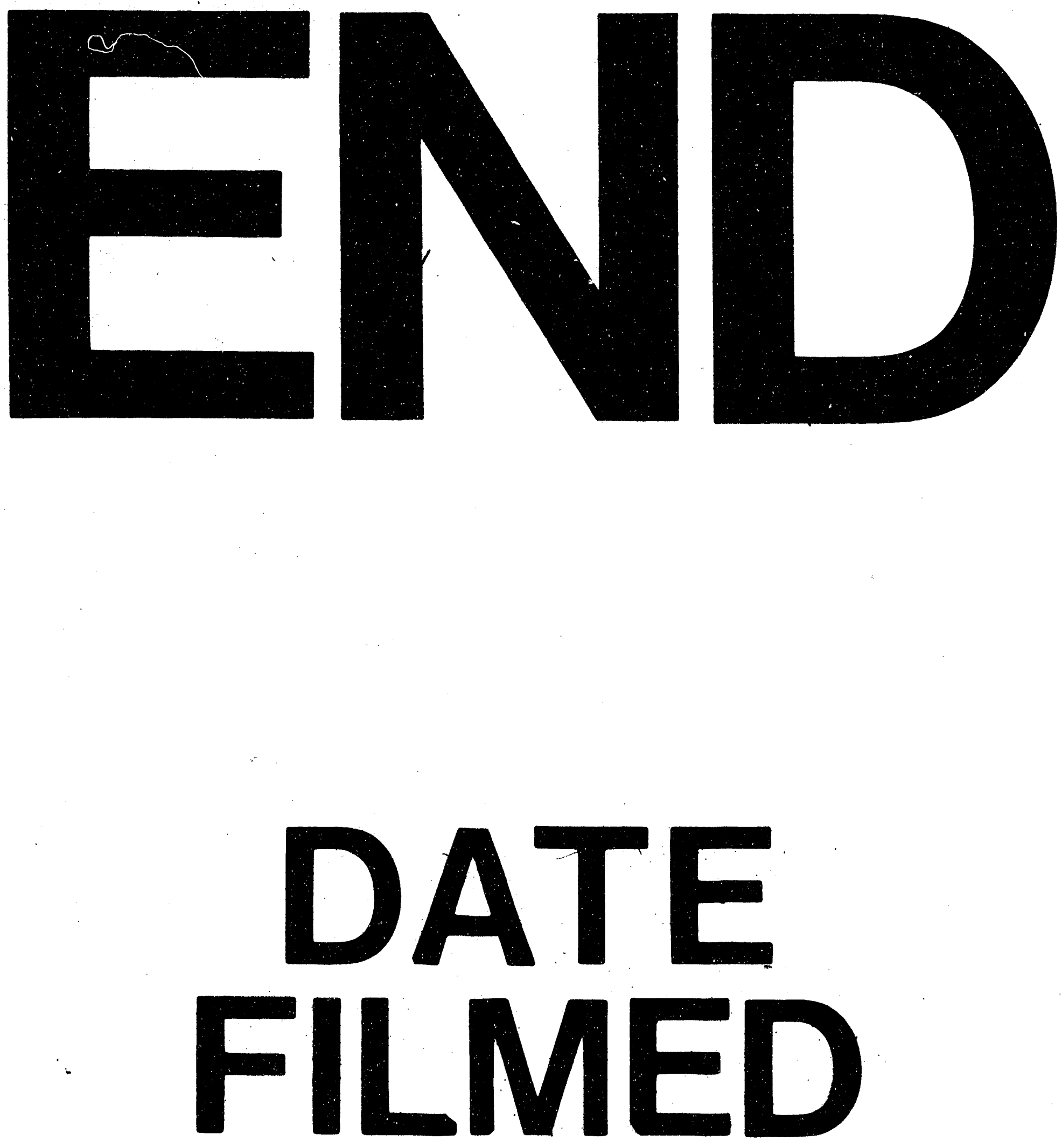

1

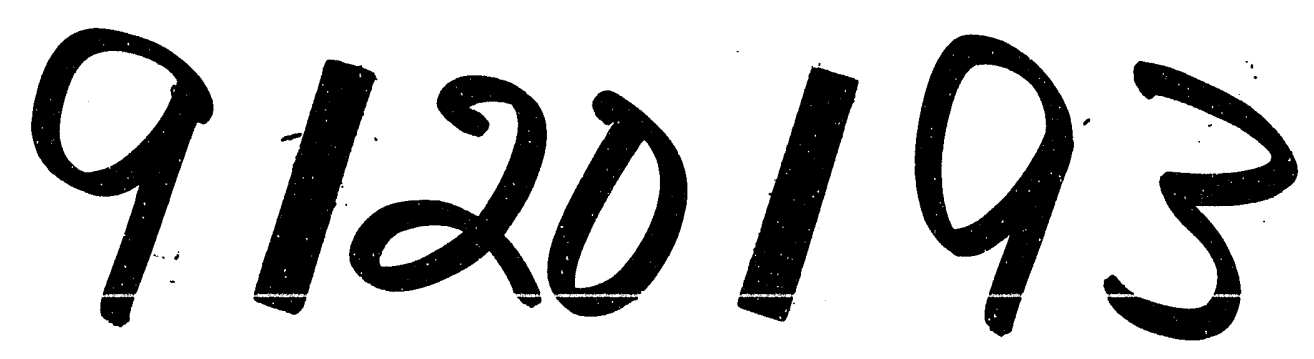


